\title{
Arguments in Critical Thinking Ability
}

\author{
$1^{\text {st Nonik Indrawatiningsih }}$ \\ STKIP PGRI Pasuruan \\ Pasuruan, Indonesia \\ nonik_pinkgirl@yahoo.com
}

\begin{abstract}
The ability to think critically is an essential skill and becomes one of the primary goals in college. A person who can think critically will be able to use appropriate criteria to evaluate an argument. There must be clear evidence and accompanied by a plausible explanation. This study aims to investigate students' critical thinking skills in determining an argument. The subject is the students of mathematics education program at one private university in Pasuruan, i.e., 31 students. Then, some students who have unique answers are selected to be interviewed further about their critical thinking ability to an argument. This research is a descriptive qualitative research. Based on the results of a written test of 31 students, there is one student who has a unique answer. The answer is different from other students, so from the results of these tests, the student is selected for the further interview. The findings of this study highlighted that the student can mention arguments with the accurate reasons and has a potential to have the ability to think critically.
\end{abstract}

Keywords - argument, Critical Thinking Ability

\section{INTRODUCTION}

Critical thinking is an essential skill that every student in Higher Education should develop. This skill is vital to assess any information, explain the reasons and be able to solve problems that have not known the solution. In addition, Douglas also said that critical thinking skills are generally recognized as essential skills and become one of the primary goals in college [1]. Critical thinking skills are preferred over algorithmic cognitive abilities. It is also expressed by Amit and Azikovitsh that the current reformation in mathematics education throughout the world includes the transition from algorithmic cognitive abilities towards higher cognitive abilities, i.e., critical thinking skills [2].

According to Ennis, critical thinking is a reflective thought which is plausible and focuses on what decisions to believe or what to do [3]. Ennis defines the ability to think critically related to decision making whether someone should believe or not in an argument [4]. One indicator of people who have the ability to think critically is he/she can evaluate the accuracy of various arguments. In the same way, Cottrell also conveys that evaluation is an essential part of critical thinking, involving a series of cognitive processes aimed identifying a problem, choosing a solution plan, and evaluating. Assuming this, people who have the ability to think critically can use appropriate criteria to evaluate an argument [5].

In a study conducted by Norris and Phillips shows that there are still many students who have difficulty in determining a claim/argument and provide a proof of the claim/argument that has been given to him [6]. Therefore, students' critical thinking skill - in this case is the skill in analyzing an argument- needs to be provoked. Furthermore, providing a proof is a crucial aspect of explaining a reason for the claim/argument [9].

Students who can examine and evaluate arguments/claims are supporting evidence that the student has critical thinking skills [10]. The ability to think critically can encourage students to think independently and solve problems in the context of everyday life [11]. As'ari states that a person who has the ability to think critically is the one who can determine whether a statement or an issue has been given arguments/claims or not [12]. A person who has the ability to think critically should be able to evaluate information from various sources of information.

Arguments are a core component of critical thinking, which includes the ability to construct its own argument, agree or disagree with claims to the information/news that has been heard $[14 ; 15 ; 16]$. Accordingly, someone who has the ability to think critically should be able to criticize news or reports from various sources of information. It involves critical thinking and argumentation skills to determine whether the claim/argument has been given right or wrong [13]. Students must justify their arguments supported by the evidence to argue that arguments must be accompanied by contradictory examples or facts that do not support

As was discussed above, students' ability in determining argument becomes an important indicator for students who have critical thinking ability. For this reason, this research has been participated by the mathematics students who have the answers which is unique or different from the others in order to find out if students who have unique answers or have the potential to have critical thinking skills. Is argument an important indicator used to track one's critical thinking ability.

\section{METHODS}

This research has been administered using a qualitative descriptive research. The subject of the research was the students of Mathematics Education Study Program at one of the private universities in Pasuruan force year 2015 amounted to 31 students. There were 31 students tested and then some of them, who have unique answers, have been selected and interviewed further. A semi-structured interview was conducted to investigate the results of tests that have been done in depth. The instrument used is the critical thinking ability of the material of triangular congruence which is made in the form of proof which refers to the indicator of critical thinking ability, namely argument identification. The instrument that is examined to the students as a following Fig. 1.

Interviews were carried out with the questions that focused on how they explained the answers already done to know whether there was a potential for critical thinking skills or not. Interviews are conducted for 20-30 minutes. The 
interviews were recorded and then transcribed and finally coded.

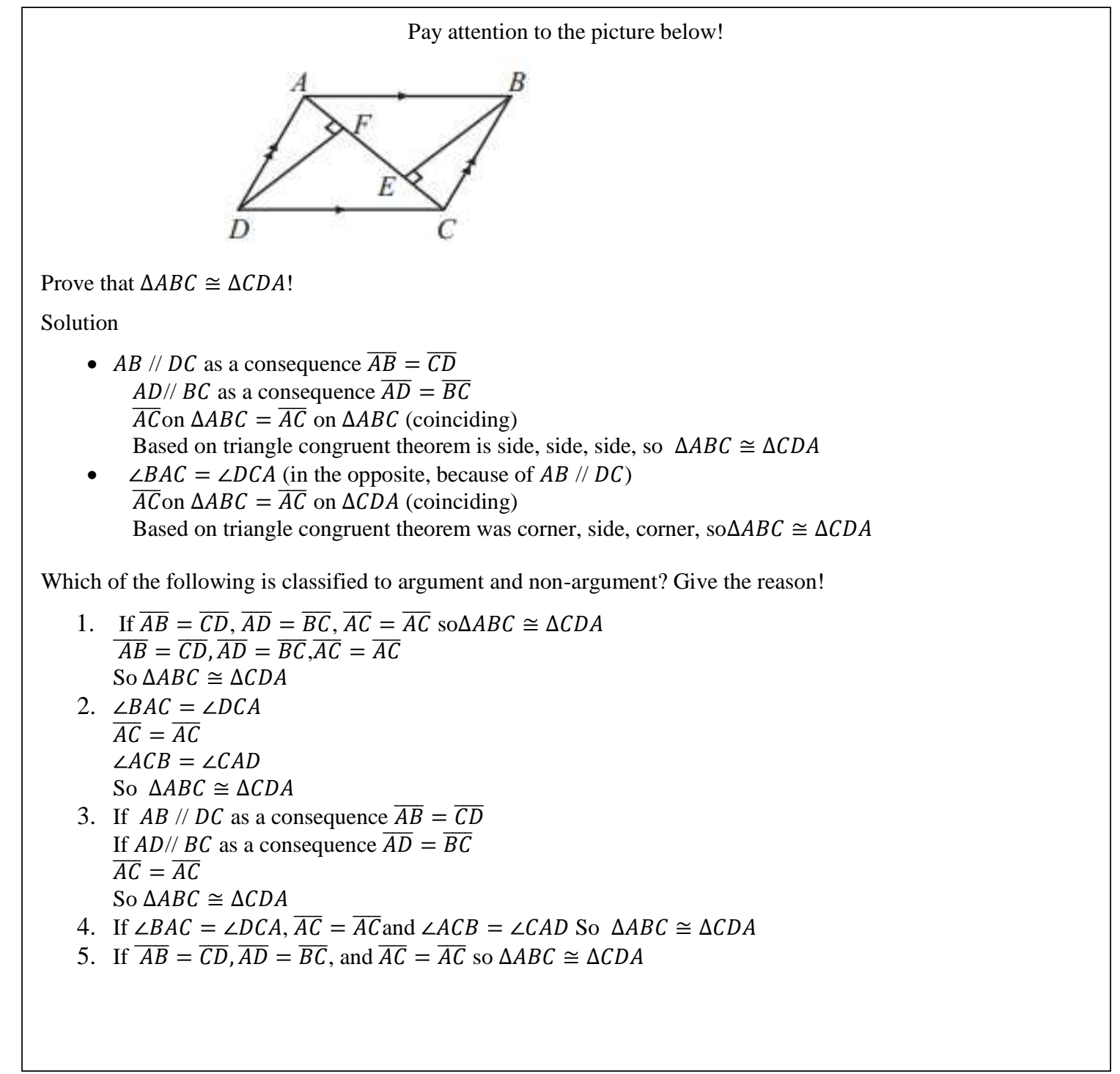

Fig. 1. Test Instrument

\section{RESULTS}

The arguments referred to in this study is a collection of statements that have a causal relationship or a sentence consisting of several statements and conclusions. This study aims to investigate students who potentially have the ability to think critically using with identifying their unique answers and examine them whether they can explain the argument or not. This suggests that the argument is a fundamental indicator that must be possessed by people who have the ability to think critically. Likewise, O'Rourke also conveys that students who are able to examine and evaluate arguments/claims are supporting evidence that the student has critical thinking skills [8]. A person who knows that the sentence/information that has been given to him or she is an argument or not is an indicator of a person who has critical thinking skills [10]. The following will explain the results and discussion of the research.

The test revealed that there was only one from 31 students who has a unique answer. The answer is different from other students so that researchers conduct further interviews with the student. Interviews here aim to identify if students who have this unique answer have the potential to have critical thinking skills and how the student explains the arguments that the researcher has given while pointing out that the argument is a fundamental indicator to track whether a person has critical thinking skills or not. Here are the results of student tests that have different answers with other students.

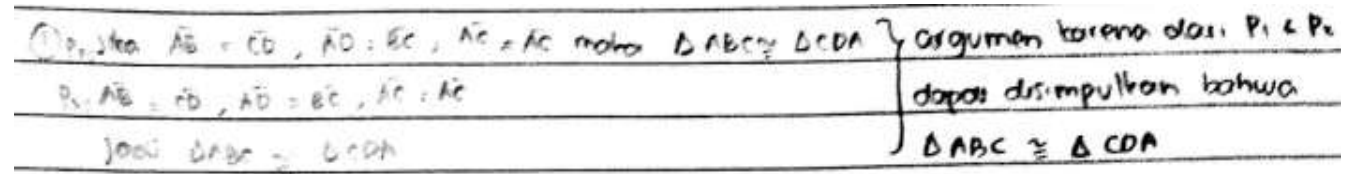

Fig. 2 the test result student about the argument 
The following was the interview result of the subject about the argument

$\mathrm{R}$ : for number 1 you answered an argument. Why?

$\mathrm{S}$ : the argument loaded conclusion, in here there was statement 1 and statement 2 and both statements could be concluded.

$\mathrm{R}$ : which one was the statements?

$\mathrm{S}:$ if $\overline{\mathrm{AB}}=\overline{\mathrm{CD}}, \overline{\mathrm{AD}}=\overline{\mathrm{BC}}, \overline{\mathrm{AC}}=\overline{\mathrm{AC}}$ so $\triangle \mathrm{ABC} \cong$ $\triangle \mathrm{CDA}$ these were statement $1 \overline{\mathrm{AB}}=\overline{\mathrm{CD}}, \overline{\mathrm{AD}}=\overline{\mathrm{BC}}$, $\overline{\mathrm{AC}}=\overline{\mathrm{AC}}$ these were statement 2 , so $\triangle \mathrm{ABC} \cong$ $\triangle \mathrm{CDA}$ was the conclusion

$\mathrm{R}$ : did the argument have to load statement and conclusion?

$S$ : yes ma'am, for example, there was no conclusion it meant that it was no argument.

$\mathrm{R}$ : was the statement same with the premise? And then the conclusion?

$\mathrm{S}$ : in my opinion they were same

$\mathrm{R}$ : could you be explained what premise/statement was?

$\mathrm{S}$ : premise was .... (while thinking). I did not define it ma'am, but the example was like number 1 if $\overline{\mathrm{AB}}=\overline{\mathrm{CD}}, \overline{\mathrm{AD}}=\overline{\mathrm{BC}}, \overline{\mathrm{AC}}=\overline{\mathrm{AC}}$ so $\Delta \mathrm{ABC} \cong \triangle \mathrm{CDA}$

$\mathrm{R}$ : how about the conclusion?

$\mathrm{S}$ : based on the conclusion was taken from some premises/statements then gave the conclusion

From the conversation above the subject can already understand that the argument must contain a set of premises and conclusions. If there is no conclusion by subject, it is not an argument. Subjects are also able to name their respective premises and conclusions. The above conversation indicates that the subject of potential possesses critical thinking skills, this is evident when in-depth interviews are conducted on arguments. The subject can determine whether it is an argument or not and clarify that the characteristics of the argument must contain the premise and conclusion while not the argument only contains the premise without conclusion. However, the subject has not connected a valid and invalid argument. He has only limited to explaining arguments and arguments, not yet getting into more in-depth content about valid and invalid arguments.

\section{DISCUSSION}

Based on the information received by the researcher, the subject is classified as a student who has the moderate academic achievement. At the time of the learning process took place in the subject is also not very active in learning. The value of his achievements was also standard. However, it turned out that based on the test results and continued with the above interview. There are findings that the subject is able to analyze the information and can mention that the information has been given an argument or not and he can give reasons/clarification why it is called arguments.

A person who cannot distinguish whether the information that has been given to him is an argument or not means the person cannot think critically. As Asari says that if one cannot determine whether an information that has been given to it is a claim/argument or not, or the person cannot distinguish which is the premise and what is the conclusion in an argument, the person is far from being said to have the ability to think critically [10]. Such people tend not to have critical thinking skills.

O'Rourke argues that students who can examine and evaluate an argument/claim, identify and evaluate an argument, and can provide supporting evidence, then the student performs an essential part of critical thinking [8]. It also occurs on this subject, he can check and assess whether the information that has been given is an argument or not, otherwise he can also give a reason why it is called an argument or not so that this subject can already be concluded that he was involved in critical thinking and have the ability to think critically.

The results show that the most crucial primary indicator in critical thinking ability is that students can define arguments or not against information that has been given to them. Evaluating arguments against existing information is an essential tool for assessing students' critical thinking skills especially knowledge of arguments. It is vital that students be able to filter the information well and not get stuck from the arguments/claims that have been said by someone. The ability to think critically is necessary for students to succeed in the future. Therefore, critical thinking skills must be applied and developed in the core curriculum and teaching and learning process to produce students who have the quality of thinking of future leaders. Therefore, it is essential to develop students' critical thinking skills in all subject lessons, especially mathematics. Mathematics learning not only teaches mathematical content.

\section{CONCLUSION}

Based on the results and discussion above, the conclusions can be drawn is as follows.

1. Based on the test results from 31 students, there is only one student who has a unique answer which subsequently conducted interviews related to the answer.

2. After interviewing the answer, it turns out this student has the potential for critical thinking skills whereas this student belongs to students who have 
3. moderate academic achievement and time of learning process in this student class is not active.

4. Arguments are the necessary and essential tool for knowing whether a person has the potential to have critical thinking skills.

\section{ACKNOWLEDGMENT}

The paper is supported by The Indonesian Endowment Fund for Education (LPDP).

\section{REFERENCES}

[1] E.P. Douglas, "Defining and Measuring Critical Thinking in Engineering," Procedia Social and Behavioral Sciences, pp. $153-159,2012$

[2] E. Aizikovitsh \& M.Amit, "Evaluating an infusion approach to the teaching of critical thinking skills through mathematics," Procedia Social and Behavioral Sciences, pp. 3818-3822, 2010

[3] R.H. Ennis, "Critical thinking and subject specificity: Clarification and needed research," Educational Researcher vol.18(3), pp 4-10. 1989

[4] R.H. Ennis. "The nature of critical thinking: an outline of critical thinking dispositions and abilities". Several times revision of a presentation at the Six International Conference on Thinking at MIT, Cambridge, MA, July 1994, 2011.

[5] S. Cottrell, Critical thinking skills: Developing useful analysis and argument. New York, NY: Palgrave Macmillan, 2005(Eds.), Metacognition in science education: Trends in current research (pp. 37-56). Dordrecht, The Netherlands: Springer, 2012

[6] S. P. Norris, \& L. M. Phillips, "Reading science: How naïve view of reading hinders so much else". In A. Zohar \& Y. J. Dori

[7] M.J. Ford, "Disciplinary authority and accountability in scientific practice and learning," Science Education, vol. 92(3), pp 404-423, 2008

[8] M. O'Rourke, UI critical thinking handbook. Retrieved from http://www.webpages.uidaho.edu/crit_think/, 2005

[9] S. Jacob, "Mathematical achievement and critical thinking skills in asynchronous discussion forums," Procedia - Social and Behavioral Sciences vol.31:2012, pp 800 - 804. 2013

[10] A.R. As'ari, Variasi Konstruk dalam Pembelajaran Matematika, Malang :CV. Bintang Sejahtera, 2016

[11] S. Sheng Lin, "Science And Non-Science Undergraduate Students' Critical Thinking And Argumentation Performance In Reading A Science News Report". International Journal of Science and Mathematics Education vol. 12, pp 1023-1046, 2013

[12] E. M. Nussbaum, \& O.V. Edwards, "Critical questions and argument stratagems: A framework for enhancing and analyzing students' reasoning practices," Journal of the Learning Sciences, vol. 20(3), pp 443-488, 2011

[13] D. Kuhn, "Teaching and learning science as argument," Science Education, vol.94(5), 810-824, 2010

[14] Y. Chen, "Teaching Scientific Core Ideas through Immersing Students in Argument: Using Density as an Example," Science Activities, vol.51, pp 78-88, 2014. 